

\section{DISCLAIMER}

This report was prepared as an account of work sponsored by an agency of the United States Government. Neither the United States Government nor any agency Thereof, nor any of their employees, makes any warranty, express or implied, or assumes any legal liability or responsibility for the accuracy, completeness, or usefulness of any information, apparatus, product, or process disclosed, or represents that its use would not infringe privately owned rights. Reference herein to any specific commercial product, process, or service by trade name, trademark, manufacturer, or otherwise does not necessarily constitute or imply its endorsement, recommendation, or favoring by the United States Government or any agency thereof. The views and opinions of authors expressed herein do not necessarily state or reflect those of the United States Government or any agency thereof. 


\section{DISCLAIMER}

Portions of this document may be illegible in electronic image products. Images are produced from the best available original document. 


\section{NOTICE}

This report was prepared as an account of work sponsored by the United States Government. Neither the United States nor the United States Department of Energy, nor any of their employees, nor any of their contractors, subcontractors, or their employees, makes any warranty, express or implied, or assumes any legal liability or responsibility for the accuracy, completeness or usefulness of any information, apparatus, product or process disclosed, or represents that its use would not infringe privately owned rights.

This report has been reproduced diectly from the best available copy.

Available from the National Technical Information Service, U. S. Department of Commerce, Springfield, Virginia 22161.

Price: Paper Copy $\$ 4.50$

Microfiche $\$ 3.00$ 
BERC/RI-78/2

Distribution Categories UC-90d

UC-92b

and UC-96

\section{PERFORMANCE OF GASOLINE AND DIESEL FUELS PRODUCED FROM COED SYNCRUDE}

By

R. L. Bechtold and R. D. Fleming

Bartlesville Energy Research Center

This report was prepared as an account of work This repod by the United States Govemment. Neither the United States nor the United States Department of Energy, nor any of their employees, nor any of dheir Entrats, subcontractors, or their employees, makes cony wartanty express or implied, or assumes any legal aritity or responsibility for the accuracy, completeness liabiliy or res of any information, apparatus, product or or usefulness of any in wo would not

process disclosed, or represents Bartlesville, Oklahoma

Date Published-June 1978

\section{UNITED STATES DEPARTMENT OF ENERGY TECHNICAL INFORMATION CENTER}




\section{CONTENTS}

$\underline{\text { Page }}$

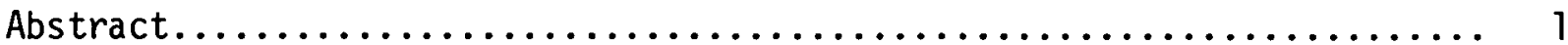

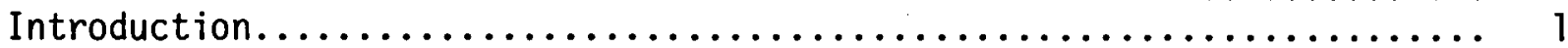

Test fuels.................................................. 2

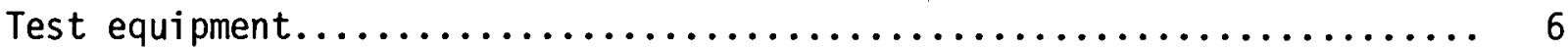

Single-cylinder engine synthetic fuel evaluation.................. 6

Use of synthetic fuels in Stirling and stratified-charge engines....... 13

Vehicle fuel study....................................... 17

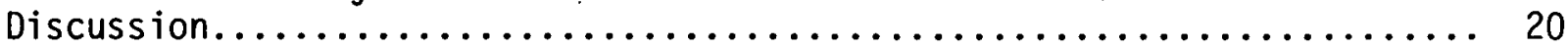

Summary $\ldots \ldots \ldots \ldots \ldots \ldots \ldots \ldots \ldots \ldots \ldots \ldots \ldots \ldots \ldots \ldots \ldots \ldots \ldots \ldots \ldots \ldots \ldots \ldots, 21$

References......................................... 22

\section{ILLUSTRATIONS}

Fig.

1. Distillation characteristics of synthetic gasoline, a blend containing $40 \%$ synthetic gasoline (synfuel blend) and a

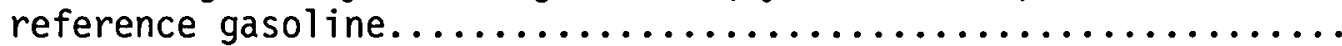

2. Distillation characteristics of a synthetic diesel fuel, a typical No. 2 diesel fuel and the diesel fuel used in reference No. 2 diesel fuel.

3. Waukesha single-cylinder test engine and dynamometer control......

4. Brake specific fuel consumption as a function of spark timing at different compression ratios (single-cylinder

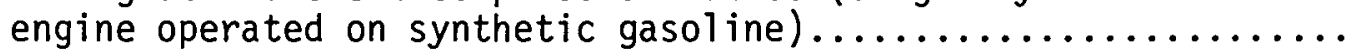

5. Brake specific fuel consumption as a function of spark timing at different compression ratios (single-cylinder engine operated on reference gasoline). 1 2
6. Brake specific fuel consumption of the single-cylinder engine using the three test fuels at 7.25 to 1 and

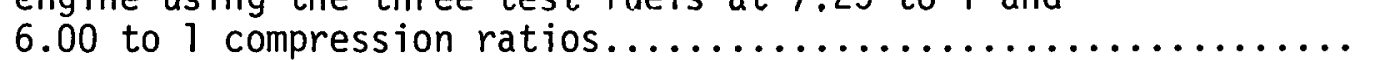
(n............

7. Hydrocarbon emissions of single-cy 1 inder engine using
the three test fuels at the 7.25 to 1 and 6.00 to 1

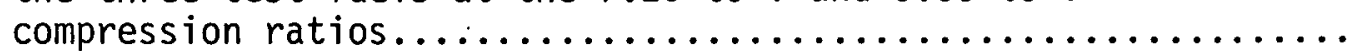

8. Carbon monoxide emissions of the single-cylinder engine using the three test fuels at 7.25 to 1 and 6.00 to 1

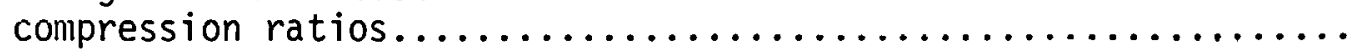
oxides of nitrogen emissions of the single-cylinder engine using the three test fuels at 7.25 to 1 and 6.00 to 1 compression ratios.

10. Indicated specific fuel consumption of the singlecylinder engine using the three test fuels at

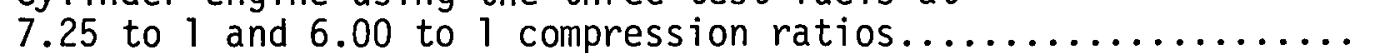

11. Consecutive cylinder pressure traces taken at $1,800 \mathrm{rpm}$ and wide-open-throttle for single-cylinder engine using the three test fuels at 6.00 to 1 and 7.25 to 1

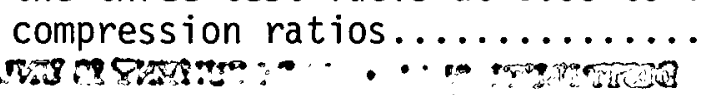




\section{ILLUSTRATIONS-continued}

Fig.

Page

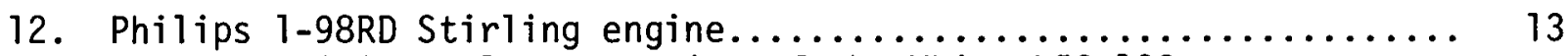

13. Brake specific fuel consumption of the White LIS-183 engine using three different test fuels at 2,000 rpm,

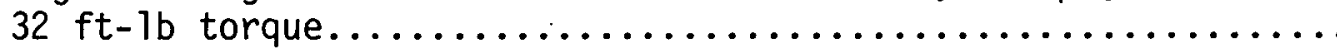

14. Brake specific hydrocarbons of the White LIS-183 engine using three different test fuels at $2,000 \mathrm{rpm}$, $32 \mathrm{ft}-1 \mathrm{~b}$ torque.

15. Brake specific carbon monoxide emissions of the White LIS-183 engine using three different test fuels at



16. Brake specific oxides of nitrogen emissions of the White LIS-183 engine using three different test fuels at. 2,000 rpm, $32 \mathrm{ft}-1 \mathrm{~b}$ torque.

17. Brake specific oxides of nitrogen emissions of the white LIS-183 engine at equal spark/injection timing for three

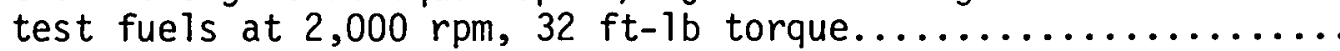

18. Fuel economy of the Astre vehicle over the EPA city and highway driving cycles using the reference gasoline

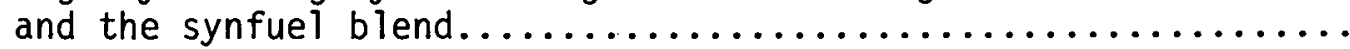

19. Exhaust emissions of the Astre vehicle over the 1975 FTP driving cycle using the reference gasoline and the synfuel blend.

20. Fuel economy at steady-state for the Astre vehicle using

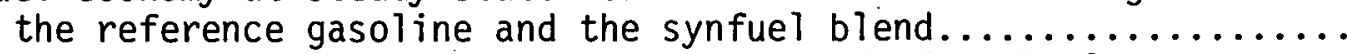

21. Hydrocarbon emissions at steady-state speeds for the Astre vehicle using the reference gasoline and the synfuel blend......

22. Carbon monoxide emissions at steady-state speeds for the Astre vehicle using the reference gasoline and the

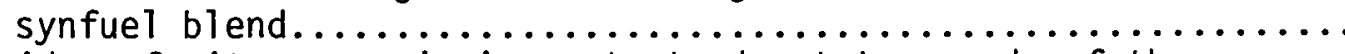

23. 0xides of nitrogen emissions at steady-state speeds of the Astre vehicle using the reference gasoline and the

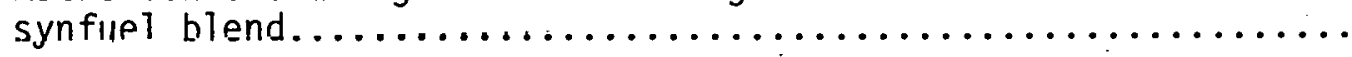

TABLES

1. Inspection data for gasolines........................... 3

2. Inspection data for diesel fuels ......................... 5

3. Waukesha RDH (removable domed head) engine general specifications............................... 8

4. Spark timing/compression ratio combinations for the three test fuels used in single-cylinder

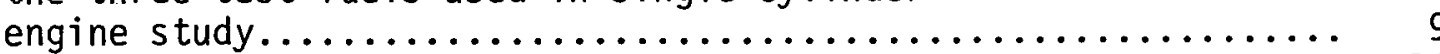

5. White LIS -183 engine specifications......................... 14

6. Astre vehicle specifications .......................... 17 


\title{
PERFORMANCE OF GASOLINE AND DIESEL FUELS PRODUCED FROM COED SYNCRUDE
}

\author{
by
}

R. L. Bechtold $d^{1}$ and R. D. Fleming ${ }^{1}$

\begin{abstract}
Fuel consumption and exhaust emissions characteristics were evaluated for gasoline and diesel fuel produced from coal liquid derived syncrude. The engine types used were: (1) current technology spark-ignition, homogeneous charge, (2) stratified-charge, and (3) Stirling.

There were no significant changes in fuel consumption or exhaust emissions between syncrude-derived fuels and conventional fuels in stratifiedcharge and Stirling engines. Because of its low $(\approx 70)$ octane number and volatility, the synthetic gasoline required a reduction in compression ratio to achieve knock-limited, MBT spark timing. This was in comparison to the reference gasoline, in a single-cylinder spark-ignited test engine, at one speed/load point. Exhaust emissions were very similar between the two fuels.

\section{INTRODUCTION}

Fuel supply for automotive systems in the transportation sector is presently totally dependent on petroleum production. In future years, due to the dwindling petroleum resources, an alternate or supplementary source of fuel supply for automotive systems will probably be required. One source of fuel would be conversion of coal to liquid and further refining of the liquid to produce fuels suitable for use in transportation systems.

Several methods have been developed to convert coal to liquid syncrude $(12)^{2}$; among them is the Char-0il-Energy Development (COED) process developed by the FMC Corp. (7). The purpose of the experimental work described in this report was to evaluate the performance of a gasoline and a diesel fuel produced from COED syncrude.
\end{abstract}

\footnotetext{
Mechanical engineer.

2Underlined numbers in parentheses refer to items in the list of references at the end of this report.
} 
The synthetic gasoline was tested in a single-cylinder research engine, a stratified-charge engine, and a Stirling engine. The synthetic diesel fuel was tested in a stirling engine. The synthetic gasoline was blended with petroleum refinery stocks to increase vapor pressure and octane number and tested in a 1977 model automobile and a single-cylinder research engine.

\section{TEST FUELS}

Two fuels (a gasoline and diesel fuel) were produced from COED syncrude by the Process Development Department, Universal 0 il Products Co. (UOP) under contract to the Department of Energy (DOE). The fuels were produced by hydrocracking the COED syncrude using UOP's Unibon process $(5,11)$. The hydrocracking followed flash distillation to remove catalyst de-activating material in the syncrude heavy bottoms. About 5 pct of the original syncrude charge was removed in the flash distillation which reduced sulfur from 0.05 to 0.01 wt pct;

nitrogen from 0.39 to 0.35 wt pct; oxygen from 0.8 to 0.5 wt pct; Conradson carbon from 0.54 to 0.07 wt pct; and heptane insolubles from 0.58 to 0.06 wt pct. The hydrocracking operating was targeted to yield distillate and naphtha in the ratio approximately 1 to 10 ; this was realized with production of 75 gal of $388^{\circ} \mathrm{F}$ end point naphtha and $7.5 \mathrm{gal}$ of distillate boiling between roughly $400^{\circ}$ and $730^{\circ} \mathrm{F}$. To achieve these yields hydrogen was consumed in the processing in the ratio of 4.57 pounds of hydrogen to 100 pounds of flashdistilled syncrude.

The process route that was chosen resulted in production of a highquality diesel fuel (the distillate) usable as-produced and the naphtha suitable either for use as blending stock or as an excellent reformer charge stock. The yield of low-octane naphtha raised questions about the depth of hydrogenation--i.e., could the processing be adjusted or altered to decrease hydrogen consumption (and thereby reduce cost) with the parallel result of higher aromaticity and generally-improved octane quality in the components of the naphtha cut. In the qualitative judgment of the technical staff speaking for the contract refiner, the material was not too deeply hydrogenated given the product distribution that was targeted. The resulting naphtha therefore was believed to represent a logical product in the process chain. Irrespective of questions about optimum process economics, the syncrude yields were judged to be suitable experimental materials for the objectives of this exploratory study. Further assessment of the syncrude processing was beyond the scope of the study.

Fuel properties of the synthetic gasoline are shown in table 1 and are compared to those of a commercial-grade, 91 octane, unleaded gasoline. (The unleaded gasoline will be called the "reference gasoline.") Inspection of data in table 1 shows that the synthetic gasoline is significantly different in gravity, vapor pressure, and octane number when compared to the reference gasoline. The octane number of the synthetic gasoline is well below that required for modern automobiles. Reid vapor pressure was 4.8 psi which is well below the value of 10.0 psi for the reference gasoline. Hydrocarbon (HC) composition of the synthetic gasoline shows that paraffin content is high, olefin content low, and aromatic content low compared to that of the reference gasoline. The synthetic gasoline is suitable for use "as is" in 
the Texaco stratified-charge engine and the Stirling engine, but is not suitable for the standard automobile engine.

The synthetic gasoline could be reformed in further processing or blended with other materials to meet vapor pressure and octane requirements of the modern automobile engines. However, further refinery upgrading of the gasoline was not feasible for this experimental program so the fuel was blended with refinery stocks from petroleum to meet octane number and vapor pressure requirements.

Targets for the blend were: Reid vapor pressure of 8 to $10 \mathrm{psi}$ and antiknock index (average of research and motor octane numbers) of 88.0 to 88.5 . Appropriate amounts of di isobutylene, isopentane, platformate, mixed xylenes, light front-end stock, and n-butane were blended with the synthetic gasoline to meet the targets for Reid vapor pressure and octane number. The final blend contained $40 \mathrm{pct}$ of the original synthetic and 60 pct of a mixture of refinery stocks described above. This blend will hereafter be referred to as the synfuel blend. Properties of the blend are given in table 1.

Distillation characteristics of the three gasolines are shown in figure 1. The distillation temperatures of the synthetic gasoline are from $20^{\circ}$ to $40^{\circ} \mathrm{F}$ higher in the boiling range from 0 to $80 \mathrm{pct}$ evaporated point when compared to those of the reference gasoline. The synfuel blend has a distillation characteristic similar to the reference gasoline. However, distillation temperatures are slightly higher in the 0 to 70 pct evaporated range and

TABLE 1. - Inspection data for gasolines

\begin{tabular}{|c|c|c|c|}
\hline & $\begin{array}{l}\text { Reference } \\
\text { gasoline } \\
(7620)\end{array}$ & $\begin{array}{c}\text { Synthetic } \\
\text { gasol ine } \\
(7702)\end{array}$ & $\begin{array}{c}\text { Synfuel } \\
\text { blend } \\
(7716)\end{array}$ \\
\hline Gravity, ${ }^{\circ}$ API $\ldots \ldots \ldots \ldots \ldots \ldots \ldots$ & 61.7 & 53.0 & 54.0 \\
\hline Reid vapor pressure, psi......... & 10.0 & 4.8 & 8.7 \\
\hline Research octane No.............. & 92.0 & 73.6 & 93.0 \\
\hline 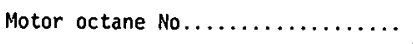 & 84.3 & 70.8 & 84.0 \\
\hline Anti-knock index $[(R+M) / 2] \ldots \ldots$ & 82.2 & 72.2 & 88.5 \\
\hline 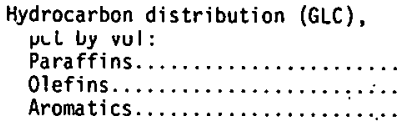 & $\begin{array}{l}64.7 \\
10.3 \\
25.0\end{array}$ & $\begin{array}{r}81.5 \\
0.0 \\
18.5\end{array}$ & $\begin{array}{l}59.9 \\
13.3 \\
26.8\end{array}$ \\
\hline Hydrogen/carbon atom ratio....... & 1.93 & $1.98^{\circ}$ & 1.87 \\
\hline Sulfur, wt pet................. & 0.05 & 0.000 & 0.006 \\
\hline 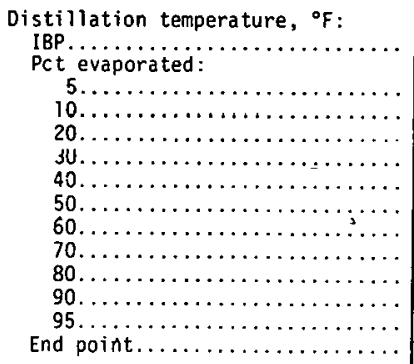 & $\begin{array}{c}88 \\
\\
112 \\
126 \\
154 \\
181 \\
204 \\
225 \\
243 \\
264 \\
294 \\
340 \\
384 \\
415\end{array}$ & $\begin{array}{l}120 \\
148 \\
166 \\
197 \\
214 \\
232 \\
251 \\
272 \\
294 \\
316 \\
345 \\
362 \\
390\end{array}$ & $\begin{array}{l}96 \\
\\
122 \\
136 \\
165 \\
197 \\
222 \\
237 \\
250 \\
263 \\
280 \\
307 \\
351 \\
376\end{array}$ \\
\hline
\end{tabular}


lower in the 70 to 100 pct evaporated range.

All three gasolines were tested in a variable compression ratio singlecylinder research engine. The synthetic and reference gasolines were tested in a Texaco stratified-charge engine and a Stirling engine. The synfuel blend and reference gasoline were tested in a 1977 Pontiac automobile with a 151-cubic-inch-displacement (CID) engine.

The properties of the synthetic diesel fuel produced from the COED syncrude are compared to two No. 2 diesel fuels in table 2. One diesel fuel (7706) was used in the experimental work. The second diesel fuel (7629) has properties similar to, those of a national average No. 2 diesel fuel (10). The cloud point and pour point of the synthetic diesel fuel are high compared to those of the No. 2 diesel fuels and indicate a possible problem of filter plugging and pumpability at lower temperatures. Calculated cetane number of the synthetic diesel fuel is 50.0 compared to 44.3 for the typical diesel fuel, and

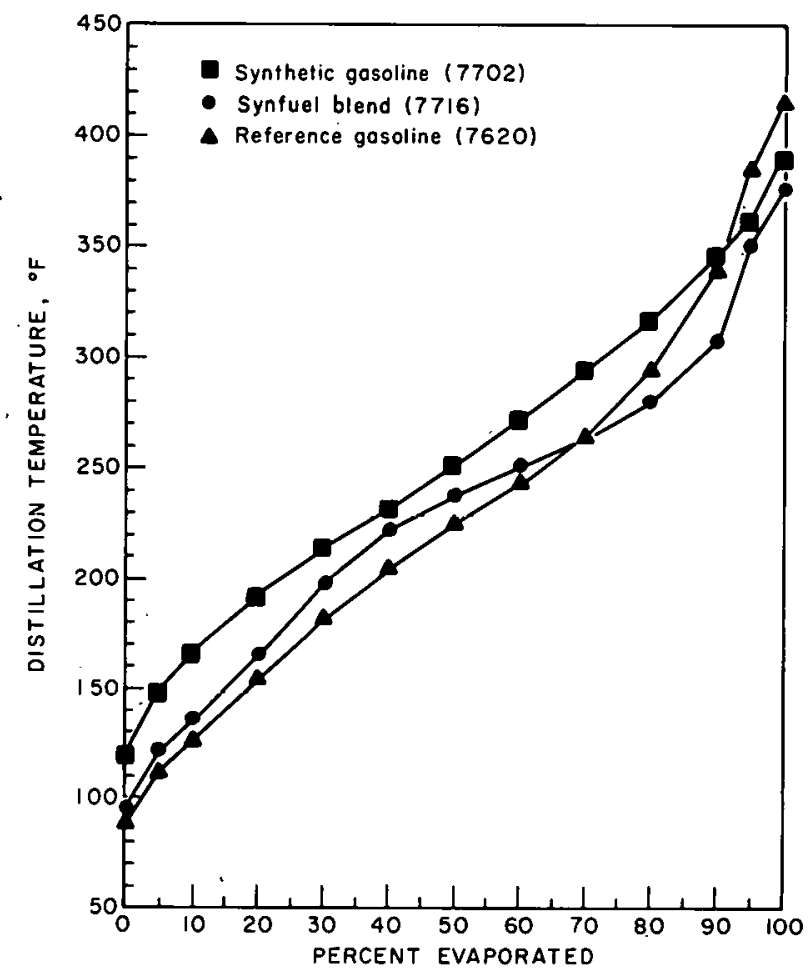

FIGURE 1. - Distillation Characteristics of Synthetic Gasoline, a Blend Containing $40 \%$ Synthetic Gasoline (Synfuel Blend) and a Reference Gasoline 46.5 for the reference diesel fuel. Paraffin content of the synthetic diesel fuel is 70 pct compared to 59 pct and 62 pct for the diesel fuels. The fuel should perform well in a diesel engine even at lower temperatures provided that the entire system was heated to maintain fuel temperatures above the cloud and pour points.

Distillation characteristics (figure 2) of the synthetic diesel fuel are similar to those of the No. 2 diesel fuels in the range of 0 to 50 pct evaporated. In the range of 50 to $100 \mathrm{pct}$ evaporated the distillation temperatures of the synthetic diesel fuel were significantly higher than that for the No. 2 diesel fuels. End point for the synthetic diesel fuel was $752^{\circ} \mathrm{F}$ compared to $626^{\circ} \mathrm{F}$ and $632^{\circ} \mathrm{F}$ for the No. 2 diesel fuels.

Owing to a limited quantity of the synthetic diesel fuel, it was tested only in a Stirling engine. 
TABLE 2. - Inspection data for diesel fuels

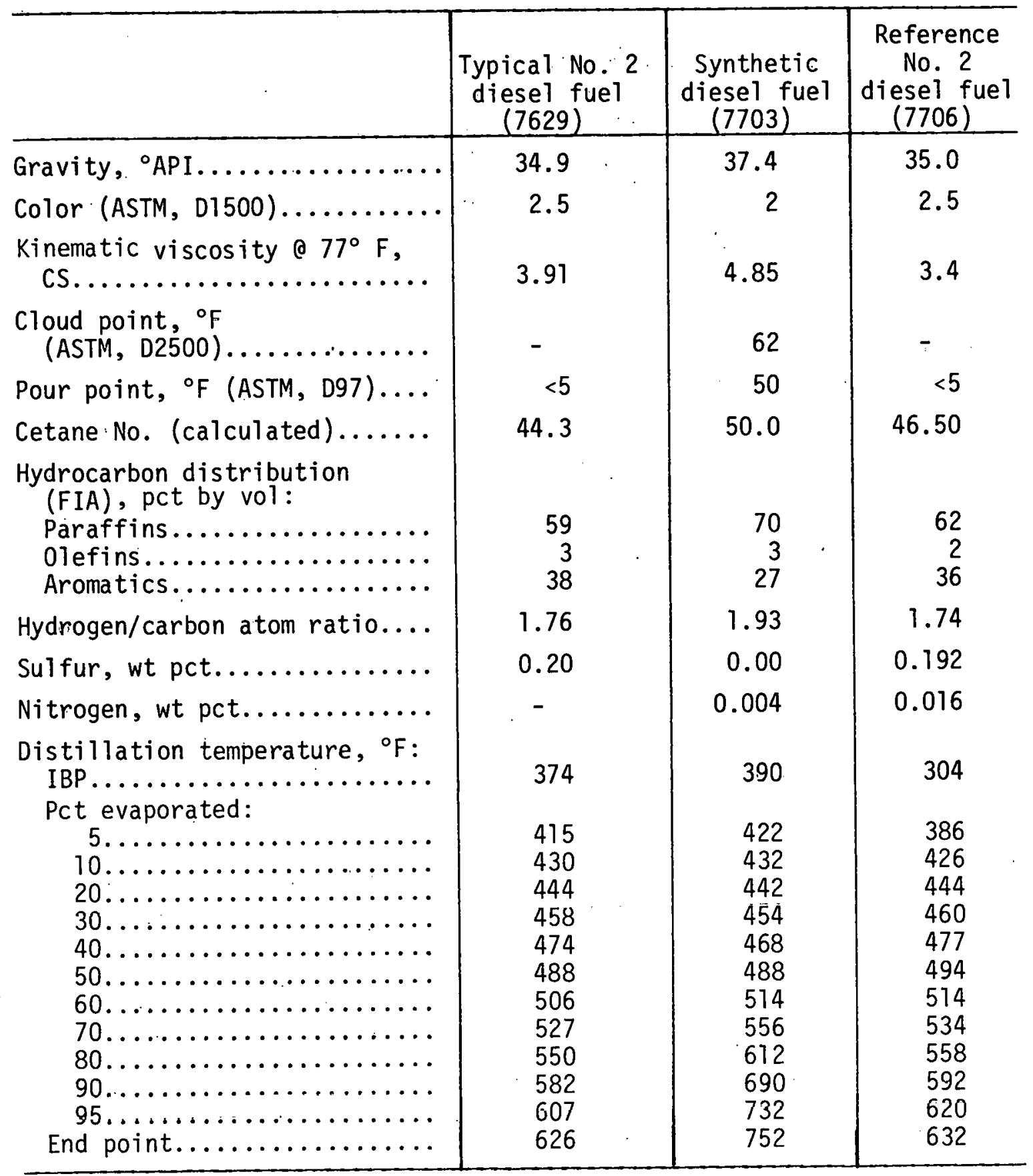




\section{TEST EQUIPMENT}

The undiluted exhaust gases were analyzed for $\mathrm{HC}$, carbon monoxide ( $\mathrm{CO})$, carbon dioxide $\left(\mathrm{CO}_{2}\right)$, oxygen, and oxides of nitrogen $\left(\mathrm{NO}_{\mathrm{X}}\right)$. The methods of analysis were: flame ionization detection (FID) for HC, nondispersive infrared (NDIR) for $\mathrm{CO}$ and $\mathrm{CO}_{2}$, polarographic instrument for $\mathrm{O}_{2}$, and chemiluminescence for $\mathrm{NO}_{\mathrm{X}}$. Air/fuel ratio was determined by calculation based on composition of exhaust gases.

The Stirling and Waukesha test engines were connected to a cradled, dc, General Electric dynamometer. This unit allowed motoring capability as well as being a power absorber. The dynamometer used with the White engine was a Mid-West eddy-current type. Both experimental set-ups used electric resistance strain gage load cells to determine engine torque.

Fuel flow and air flow were measured physically as a check on the carbon balance air/fuel calculation. Fuel flow was measured with a positive displacement meter. Air flow was measured with a laminar flow meter for the White engine and by a turbine meter for the Stirling and single-cylinder engines. Engine speed for all three set-ups was determined using a magnetic pick-up and a 60 tooth gear mounted on the output shaft.

The Astre vehicle tests were conducted on a Clayton chassis dynamometer in a controlled environment. Exhaust emissions were analyzed using a constant volume sampling system (CVS) and the methods of analysis were the same as were used in the single-cylinder engine tests. Corrections to $\mathrm{NO}_{\mathrm{X}}$ emissions were made for the humidity of the air in the test cell. All emissions measurements and EPA mileage computations conform to Federal Regulations.

\section{SINGLE-CYLINDER ENGINE SYNTHETIC FUEL EVALUATION}

A single-cylinder Waukesha test engine (figure 3 ) was used to determine specific fuel consumption and emissions. The fuels were synthetic gasoline (7702), the synfuel blend (7716), and the unleaded reference gasoline (7620). The Waukesha engine (specifications in table 3 ) is a four-stroke cycle, carbureted, spark-ignition engine with variable compression ratio adjustable 
over a wide range. For all tests the engine was operated at wideopen-throttle and speed set at $1,800 \mathrm{rpm}$. The air-fuel ratio (A/F) was se.t so that the exhaust gases contained 3 pct free oxygen. This was to simulate operation just slightly lean of stoichiometric or about 0.865 eouivalence ratio.

Knock-1 imited compression ratio and minimum spark timing for best torque (MBT) were determined for two fuels (synthetic gasoline and reference gasoline). The synfuel blend had properties similar to those of the reference gasoline. Therefore, the compression ratio and spark timing used in the test program for the synfuel blend were the same as those used for the reference gasoline.

For each fuel the compression ratio was first set at a low value. When spark timing was adjusted from $10^{\circ}$ before top dead center (BTDC) to $50^{\circ}$ BTDC, no knock was encountered, and a typical fish-hook curve was generated on a brake specific fuel consumption (BSFC) vs. spark timing plot. Compression ratio was then increased in increments of 0.25 , and spark timing was advanced by 5

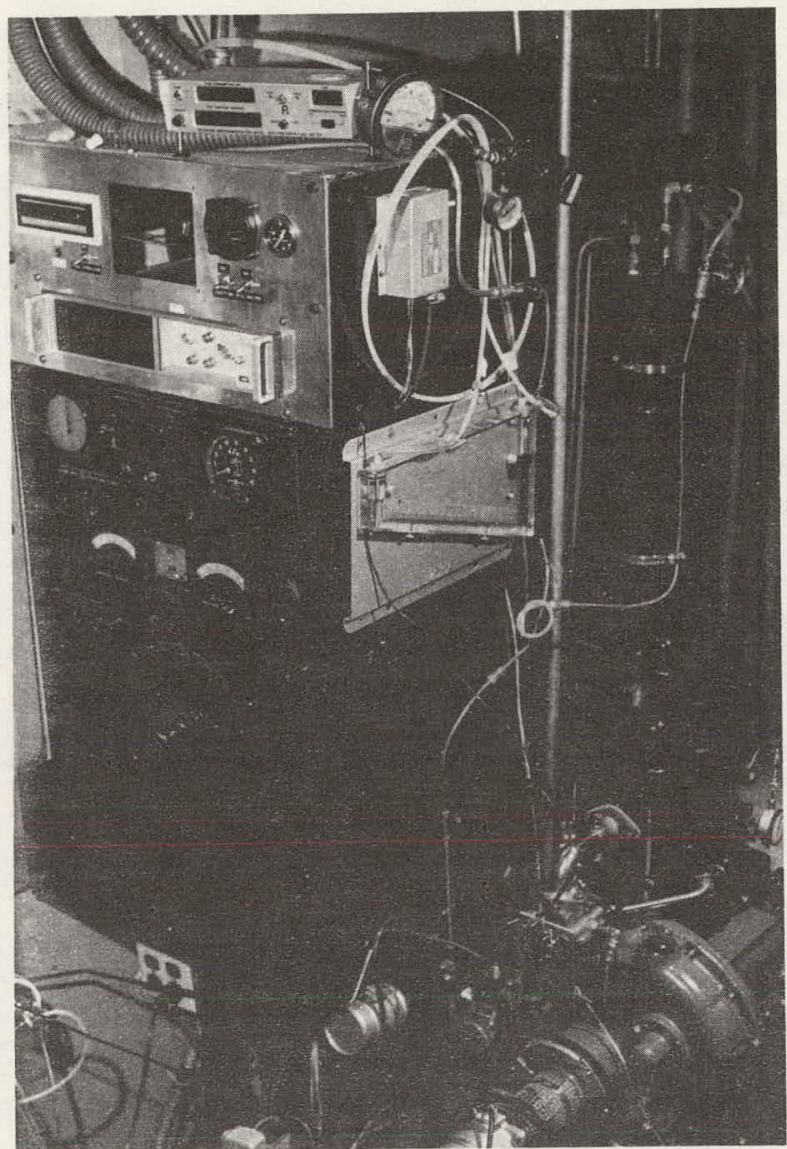

FIGURE 3. - Waukesha Single-Cylinder Test Engine and Dynamometer Control degree increments from $10^{\circ}$ to $50^{\circ}$

BTDC or the knock limit. Figure 4 shows the results from tests with synthetic gasoline.

The highest compression ratio obtainable at MBT spark timing chosen for this fuel was 6.0 to 1 at $30^{\circ}$ BTDC, respectively. From the 6.0 compression curve in figure 4 , it can be seen that BSFC was the same at spark timings of $35^{\circ}$ and $30^{\circ}$ BTDC. However, intermittent knock occurred at $35^{\circ}$ BTDC and $30^{\circ}$ BTDC was chosen. Figure 5 shows a similar series of curves for the reference gasoline. From these curves it was determined that the highest compression ratio at MBT spark timing was 7.25 to 1 . The corresponding MBT spark timing was $25^{\circ}$ BTDC.

The three fuels were then tested at the two compression ratios determined to be optimum under the stated criteria. Because of its low octane rating, the synthetic gasoline required spark retard for operation with a 7.25 to 1 compression ratio. It was found that spark timing of $15^{\circ}$ BTDC 
TABLE 3. - Waukesha RDH (removable domed head) engine general specifications

Type............ 4-stroke cycle

No. of cylinders...... 1

Charge preparation.... homogeneous

Ignition............ spark plug; breakerless electronic

Bore and stroke, in... $3-13 / 16 \times 3-5 / 8$

Displacement, in $^{3} \ldots .441 .38$

Compression ratio range............ 5-16:1

Date of manufacture... May, 1975

Serial No.......... 278162

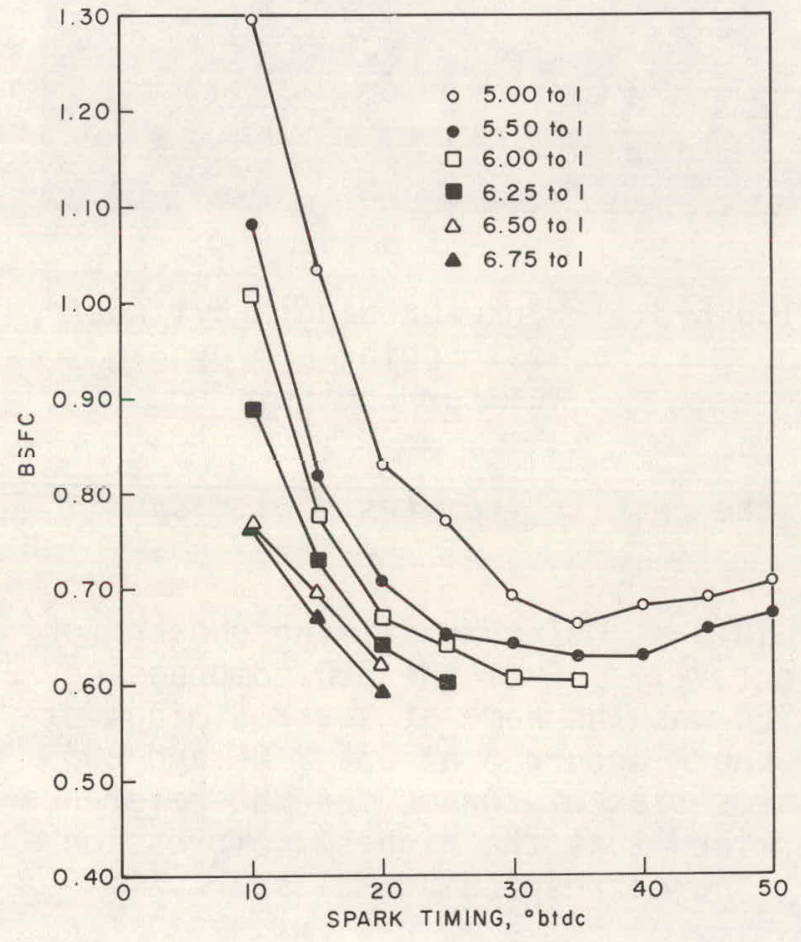

FIGURE 4. - Brake Specific Fuel Consumption as a Function of Spark Timing at Different Compression Ratios (SingleCylinder Engine Operated on Synthetic Gasoline)

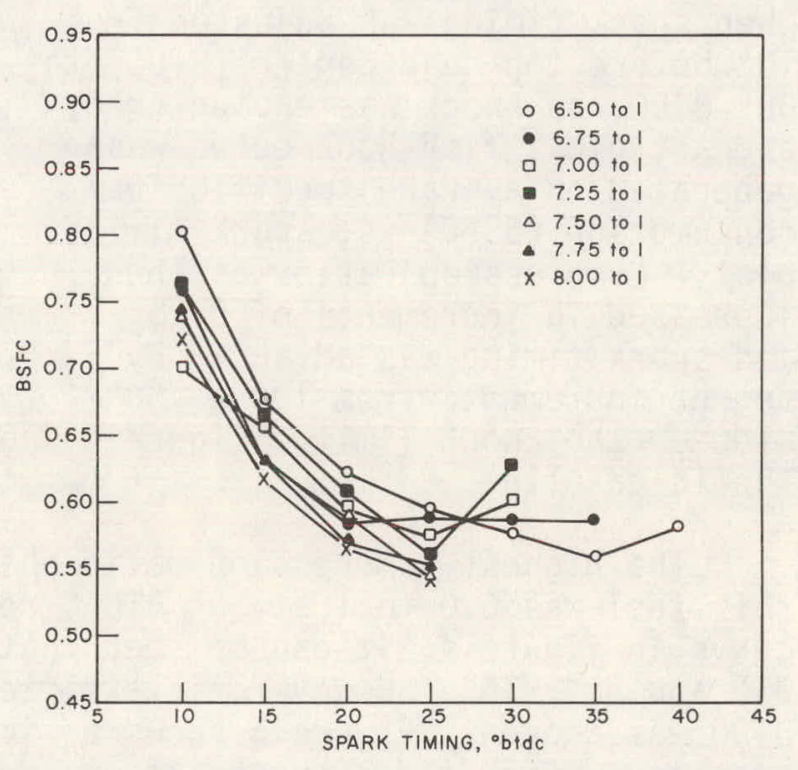

FIGURE 5. - Brake Specific Fuel Consumption as a Function of Spark Timing at Different Compression Ratios (Single-Cylinder Engine Operated on Reference Gasoline) 
allowed the engine to burn the synthetic gasoline with incipient knock. Table 4 shows the spark timing used for the three fuels at the two compression ratios studied.

TABLE 4. - Spark timing/compression ratio combinations for the three test fuels used in singlecylinder engine study

\begin{tabular}{c|c|c}
\hline \multirow{2}{*}{ Test fuel } & \multicolumn{2}{|c}{ Spark timing, degree BTDC } \\
\cline { 2 - 3 } & \multicolumn{2}{|c}{ Compression ratio, } \\
\cline { 2 - 3 } & 6.00 to 1 & 7.25 to $~$ \\
\hline Synthetic gasoline..... & 30 & 15 \\
Synfuel blend.......... & 30 & 25 \\
Reference gasoline..... & 30 & 25 \\
\hline
\end{tabular}

At the 6.00 to 1 compression ratio, the spark timing for the synfuel blend and the reference gasoline was set at $30^{\circ}$ BTDC. This was equal to the MBT spark timing found for the synthetic gasoline. This was done so that a direct comparison of the fuels at the same compression ratio and spark timing could be made. More efficient utilization of the synfuel blend and the reference gasoline could result from more spark advance at the 6.00 to 1 compression ratio, but it was desired that direct comparison to the synthetic gasoline be made.

At the 7.25 to 1 compression ratio the MBT timing for the synfuel blend and the reference gasoline was $25^{\circ}$ BTDC. Using the synthetic gasoline at this compression ratio, the knock-limited spark timing was $15^{\circ}$ BTDC. The synthetic gasoline was not tested at $25^{\circ}$ BTDC because operation in the knocking region was considered unacceptable.

The BSFC results from these test points (figure 6 ) show no significant difference between the three fuels at the 6.00 to 1 compression ratio. At the 7.25 to 1 compression ratio the reference gasoline and synfuel blend showed lower BSFC's than the synthetic gasoline. This can be attributed to the knock-1imited spark timing of $15^{\circ}$ BTDC needed for satisfactory operation of the synthetic gasoline. There was no significant difference in BSFC between the reference gasoline and synfuel blend. The absolute value of BSFC for these two fuels at the higher compression ratio was lower than those obtained at 6.00 to 1 compression ratio. This is in agreement with classical information on four-stroke cycle, spark-ignited, homogeneous charge internal combustion engines (). . 
The A/F ratio was maintained constant at 16.8 to 1.0 for all tests with the single-cylinder engine. The maximum variation in $A / F$ between tests involving the three fuels was about $0.2 \mathrm{~A} / \mathrm{F}$.

Hydrocarbon emissions for the three test fuels (figure 7) were similar when operated at the same compression ratio and the same spark timing. The HC emissions were higher at the higher compression ratio. This is consistent with previous work relating $\mathrm{HC}$ emissions to compression ratio (1) for 4stroke, spark-ignited, homogeneous charge engines. The HC emissions at 7.25 to 1 compression ratio were directionally lower for the synthetic gasoline compared to the reference gasoline or the synfuel blend. This result could be expected from a reduction in spark timing as was needed for knock-free operation for the synthetic gasoline at the 7.25 to 1 compression ratio (4).

Carbon monoxide emissions were unaffected in changing from one to another of the test fuels (figure 8). The $\mathrm{CO}$ emissions at the 7.25 to 1 compression ratio for the reference gasoline and the synthetic gasoline appear quite high relative to the others, however the difference is not statistically significant.

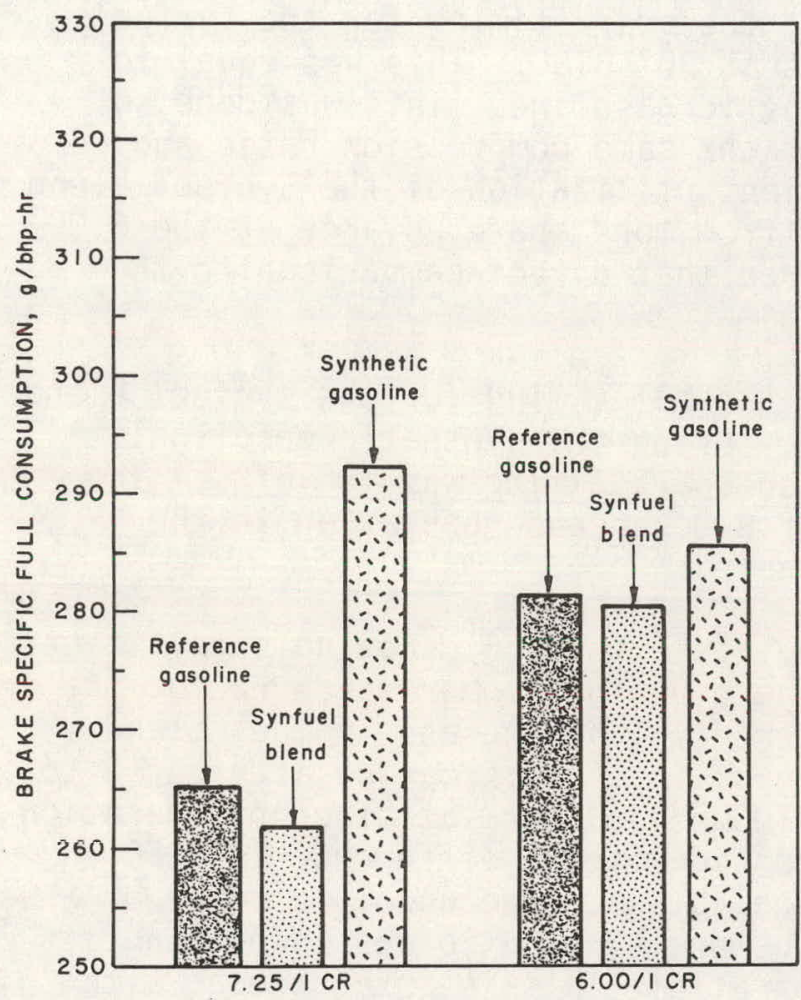

FIGURE 6. - Brake Specific Fuel Consumption of the SingleCylinder Engine Using the Three Test Fuels at 7.25 to 1 and 6.00 to 1 Compression Ratios

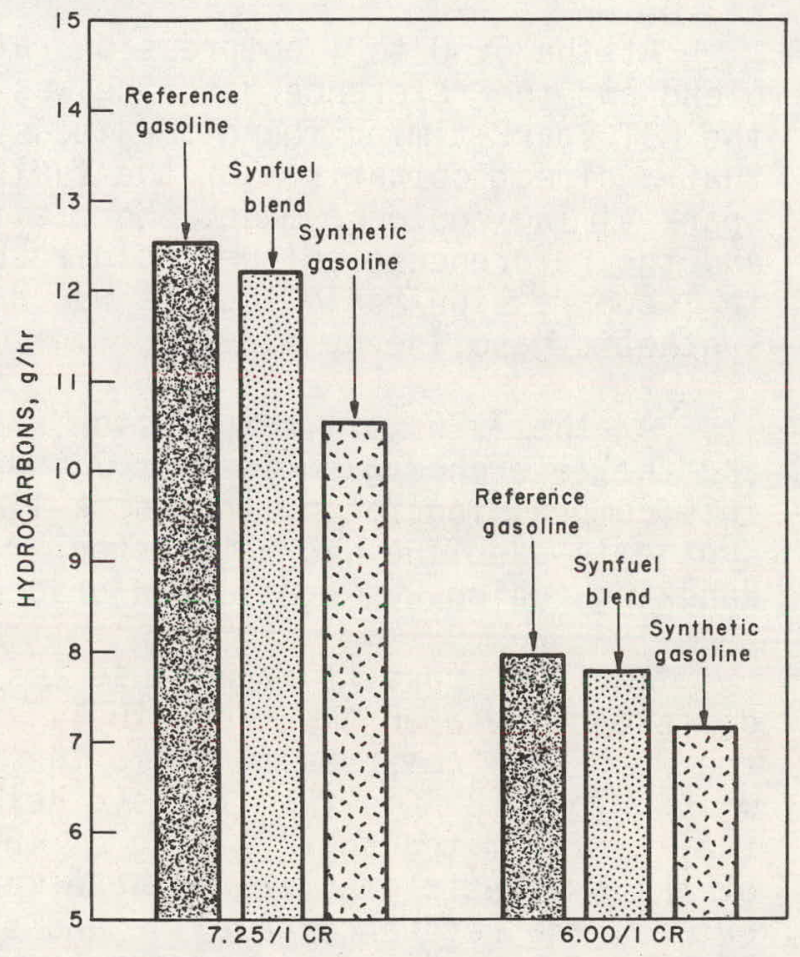

FIGURE 7. - Hydrocarbon Emissions of Single-Cylinder Engine Using the Three Test Fuels at the 7.25 to 1 and 6.00 to 1 Compression Ratios 
Oxides of nitrogen emissions (figure 9) were not significantly different between any of the fuels. At the 7.25 to 1 compression ratio, $\mathrm{NO}_{\mathrm{x}}$ emissions were lowest for the synthetic gasoline compared to the other fuels. This is consistent with previously reported data (3) for retarded spark timing at a constant compression ratio. At equal spark timing, an increase in compression ratio usually results in increased $\mathrm{NO}_{\mathrm{x}}$ emissions (6). In this case, $\mathrm{NO} \mathrm{x}_{\mathrm{X}}$ emissions at the two compression ratios are virtual7y the same because of the advanced spark timing of the 6.00 to 1 compression ratio compared to the 7.25 to 1 compression ratio.

The indicated specific fuel consumption (ISFC) of the test fuels at the two compression ratios tested (figure 10) follow the same trend as the BSFC data (figure 6). The ISFC values were determined from cylinder pressure traces taken using a spark plug pressure transducer. The pressure at each point in the cycle was multiplied by its corresponding cylinder volume and the resulting function integrated over a complete 4-stroke cycle. This calculated work per cycle was combined with the nominal test point speed and fuel consumption to yield values of ISFC.

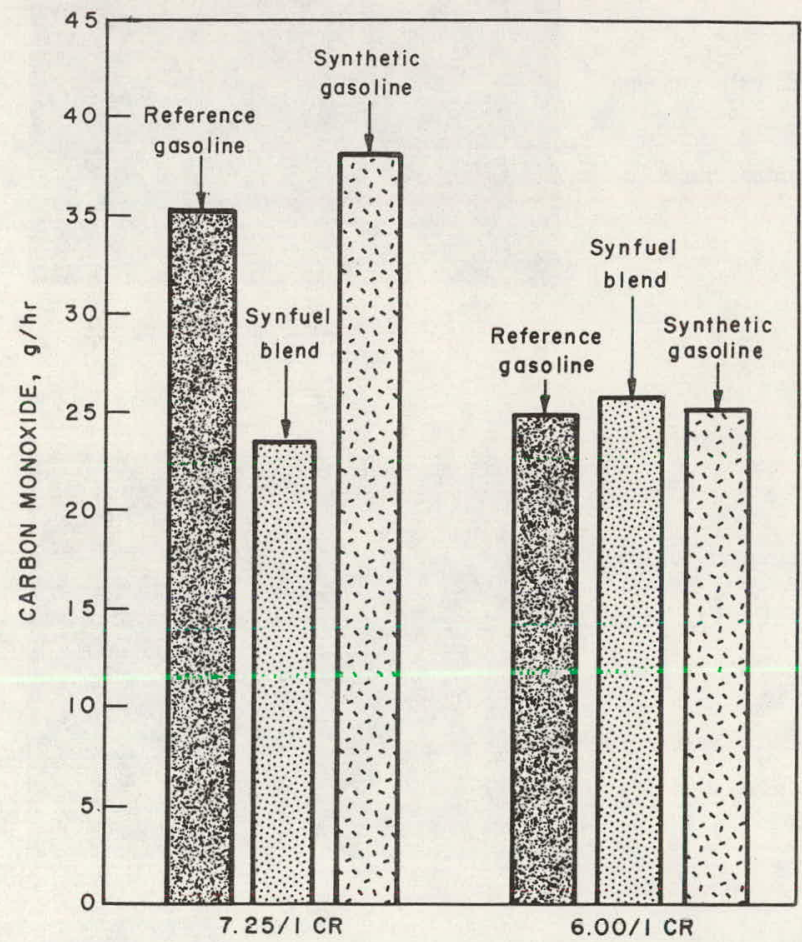

FIGURE 8. - Carbon Monoxide Emissions of the Single-Cylinder Engine Using the Three Test Fuels at 7.25 to 1 and 6.00 to 1 Compression Ratios

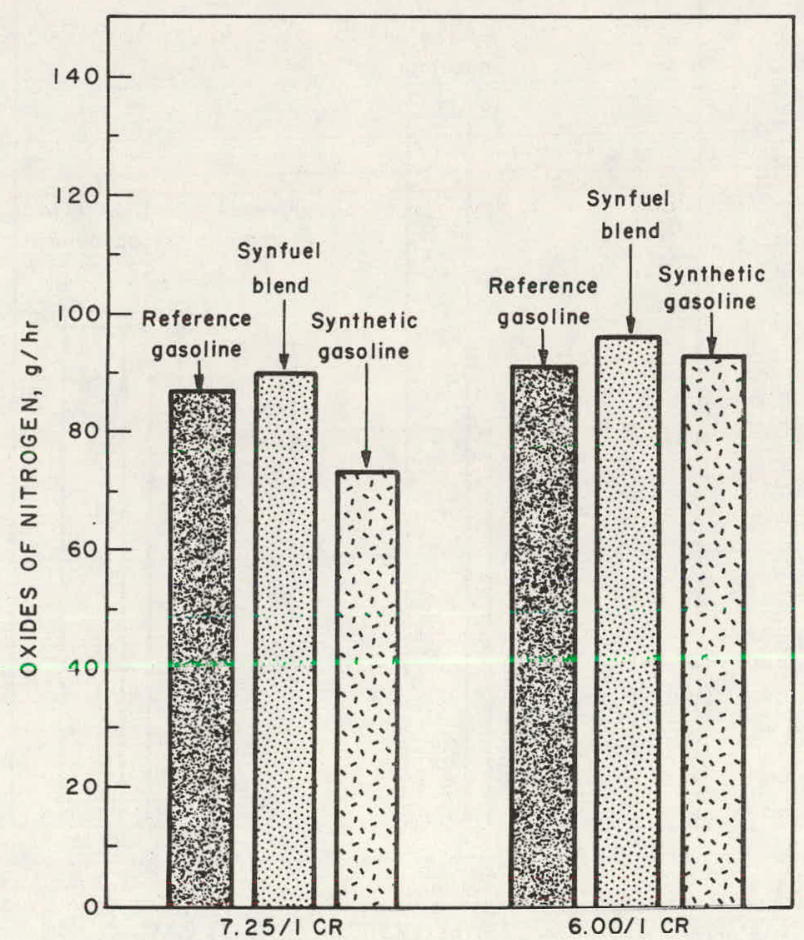

FIGURE 9. - Oxides of Nitrogen Emissions of the SingleCylinder Engine Using the Three Test Fuels at 7.25 to 1 and 6.00 to 1 Compression Ratios 
At the 7.25 to 1 compression ratio, the synthetic gasoline had a much higher ISFC compared to the reference gasoline or the synfuel blend. The difference can be attributed to the spark timing retard necessary for satisfactory operation of the synthetic gasoline at 7.25 to 1 compression ratio. At 6.00 to 1 compression ratio, there was no significant difference in ISFC between the three fuels. The ISFC values at 6.00 to 1 compression ratio were slightly higher than at the 7.25 to 1 ratio. This could be expected from classical data ( $\underline{8})$ on spark timing/compression ratio relationships of 4-stroke cycle, spark-ignited, homogeneous charge engines.

Cylinder pressure traces taken while operating with the three test fuels at the two compression ratios are shown in figure 11. At 6.00 to 1 compression ratio and equal spark timing of $30^{\circ}$ BTDC, the traces for all three fuels are similar. (The raised dot between peaks and the dot slightly out of line near the peak pressure is an indicator pulse aligned with top dead center.) This suggests nearly equal combustion between the three fuels and is substantiated by the BSFC and emissions results.

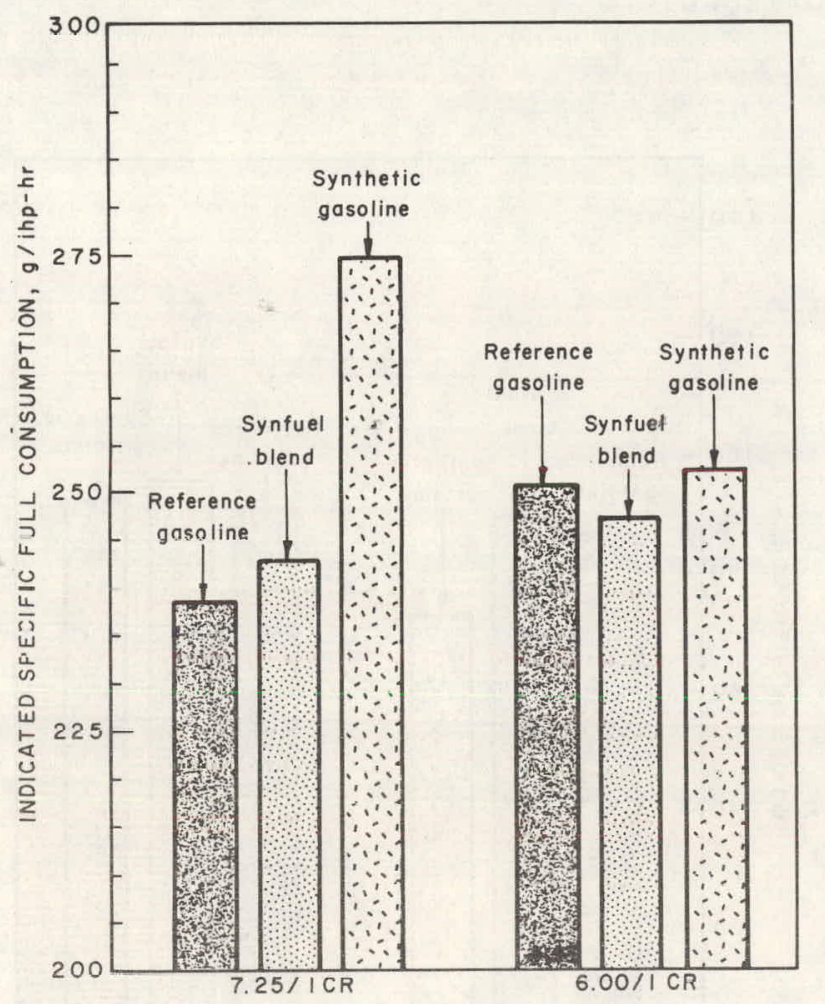

FIGURE 10. - Indicated Specific Fuel Consumption of the SingleCylinder Engine Using the Three Test Fuels at 7.25 to 1 and 6.00 to 1 Compression Ratios
Reference gasoline

Synthetic gasoline

Synfuel blend

Reference gasoline $25^{\circ}$ btdc s.t.

Synthetic gasoline $15^{\circ}$ btdc s.t.

Synfuel blend $25^{\circ}$ btdc s.t.

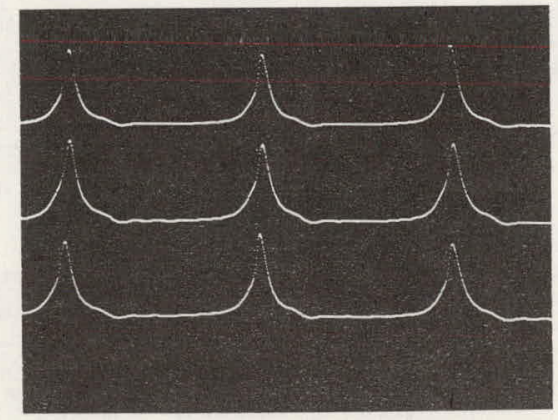

6.00 to 1 compression ratio; $30^{\circ} \mathrm{btdc}$ spark timing

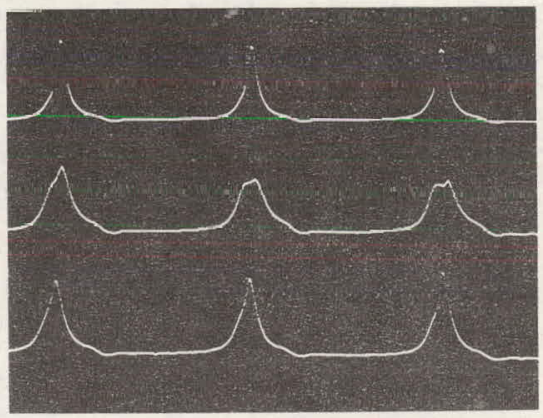

7. 25 to 1 compression ratio

FIGURE 11. - Consecutive Cylinder Pressure Traces Taken at 1,800 rpm and Wide-Open Throttle for SingleCylinder Engine Using the Three Test Fuels at 6.00 to 7 and 7.25 to 1 Compression Ratios 
At 7.25 to 1 compression ratio, a major difference in the curves results when using the synthetic gasoline because of the spark retard necessary for satisfactory, knock-free operation. The lower peak cylinder pressure when using the synthetic gasoline reduces energy conversion efficiency with a resulting increase in fuel consumption. The reference gasoline and the synfuel blend show very similar pressure traces and have similar fuel consumption and emissions.

\section{USE OF SYNTHETIC FUELS IN STIRLING AND STRATIFIED-CHARGE ENGINES}

The synthetic gasoline in its present form with an octane rating in the low $70^{\prime}$ 's is not suitable for direct use in current 4-stroke, spark-ignition engines. However, Stirling cycle engines which make use of external, continuous combustion may use fuels wi thout any cetane or octane requirements. The Stirling engine enables direct comparisons between the reference gasoline and the synthetic gasoline without making any engine adjustments to accommodate either fuel, assuming that the fuels do not affect the operation of the burner.

A Philips 1-98RD Stirling engine (figure 12) was available for experimental work. This engine is a singlecylinder displacer type, rhombic drive model using helium as a working fluid. The nominal maximum power output is $10 \mathrm{hp}$, and the maximum working fluid pressure is 1,600 psi. It was intended for use in industrial-type applications. The speed/load point chosen for evaluation was 2,000 rpm and 12.0 ft- $1 \mathrm{~b}$ of torque which corresponds to $4.6 \mathrm{bhp}$ output and 1,100 psi average working fluid pressure.

The results between the two fuels showed no significant differences in fuel consumption or exhaust emissions at a given engine setting. Brake specific fuel consumption was $0.6 \mathrm{lb} /$ bhp-hr at this speed/load point. Brake specific emissions results were as follows: unburned hydrocarbons, $0.02 \mathrm{~g} / \mathrm{bhp}-\mathrm{hr}$; CO emission rate, 1.27 $\mathrm{g} / \mathrm{bhp}-\mathrm{hr}$; and NOx emissions, $1.58 \mathrm{~g} /$

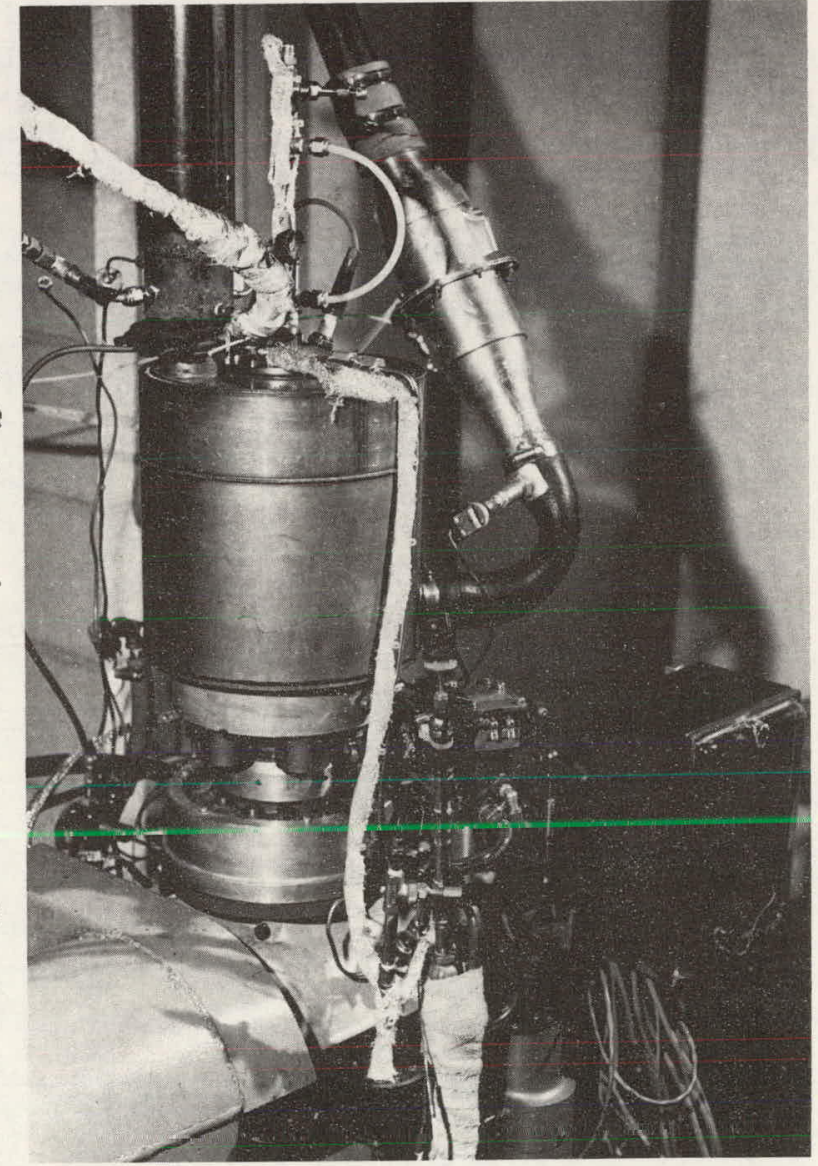

FIGURE 12. - Philips 1-98RD Stirling Engine bhp-hr. 
Because of its wide fuel appetite, the Stirling engine was used for a direct comparison between the synthetic diesel fuel (7703) and the No. 2 diesel fuel (7706). The speed/load point used was again 2,000 rpm and $12.0 \mathrm{ft}-1 \mathrm{~b}$ of torque. The results suggest that there were no significant differences in fuel consumption or exhaust emissions between the two fuels. The BSFC was $0.6 \mathrm{lb} / \mathrm{bhp}-\mathrm{hr}$ for both fuels. Brake specific emissions results for the two fuels were as follows: unburned hydrocarbons, $0.0075 \mathrm{~g} / \mathrm{bhp}-\mathrm{hr}$; CO output, $1.20 \mathrm{~g} / \mathrm{bhp}-\mathrm{hr}$; and $\mathrm{NO}_{\mathrm{x}}, 1.40 \mathrm{~g} / \mathrm{bhp}-\mathrm{hr}$. These emissions are slightly lower than the emissions from operation with reference gasoline or the synthetic gasoline.

An internal combustion engine capable of burning a wide range of fuels is the White Motor Corp. LIS-183 engine. This engine is a stratified-charge, 4-stroke cycle, unthrottled, fuel-injected, and spark-ignited engine utilizing the Texaco Controlled Combustion System. (See specifications in table 5.) The combustion system is such that the fuel used does not have to meet any specific octane or cetane number requirement. This engine was chosen for a comparison between the reference gasoline, the synthetic gasoline, and the No. 2 diesel fuel $(7706)$. The speed/load point at which the three fuels were evaluated was 2,000 rpm and $32 \mathrm{ft}-1 \mathrm{~b}$ of torque.

Experimental test work shows (2) that the White LIS-183 engine operates best under most circumstances when the fuel injection timing and spark timing are the same.

The BSFC of the White LIS-183 engine using the synthetic, reference gasoline and No. 2 diesel fuels, and corresponding spark/injection timing settings is shown in figure 13. The values of BSFC for the rèference gasoline and the synthetic gasoline are very much the same. The BSFC using the

TABLE 5. - White LIS-183 engine specifications

Bore, inches..................

3.875

Stroke, inches.............. 3.875

Number of cylinders........... 4

Displacement, cu. in........... 183

Firing order.............. 1-3-4-2

Compression ratio............. 11.68 to 1

Power rating................ 85 BHP 24,000 rpm

Ignition system............. light triggered, transistorized

Fuel system................ mechanical fuel injection

Combustion system.............. Texaco controlled combustion system 
No. 2 diesel fuel (7706) was less than what was obtained from the other two fuels by about $0.1 \mathrm{lbm} / \mathrm{bhp}-\mathrm{hr}$. (These values represent the minimum fuel consumption possible through spark/injection timing optimization for the three fuels at this particular speed/load point. These values do not represent the best results possible with this engine.)

The BSHC emissions of the White LIS-183 engine (figure 14) show a wide variation among the three test fuels. Hydrocarbon emissions are relatively high for the reference gasoline and slightly less for the synthetic gasoline. The No. 2 diesel fuel (7706) yielded HC emissions about one-third that of the synthetic gasoline and almost one-quarter that of the reference gasoline. These differences could be due to incomplete combustion of lean regions in the cylinder. Lean regions are more likely as the vapor pressure of the fuel is increased, as is the case with the synthetic and reference gasoline.

Brake specific CO emissions show little variation among the three test fuels (figure 15). Carbon monoxide emissions can usually be characterized as a function of A/F ratio alone (9) when dealing with a single fuel. In this situation, the differences indicate basic combustion characteristics

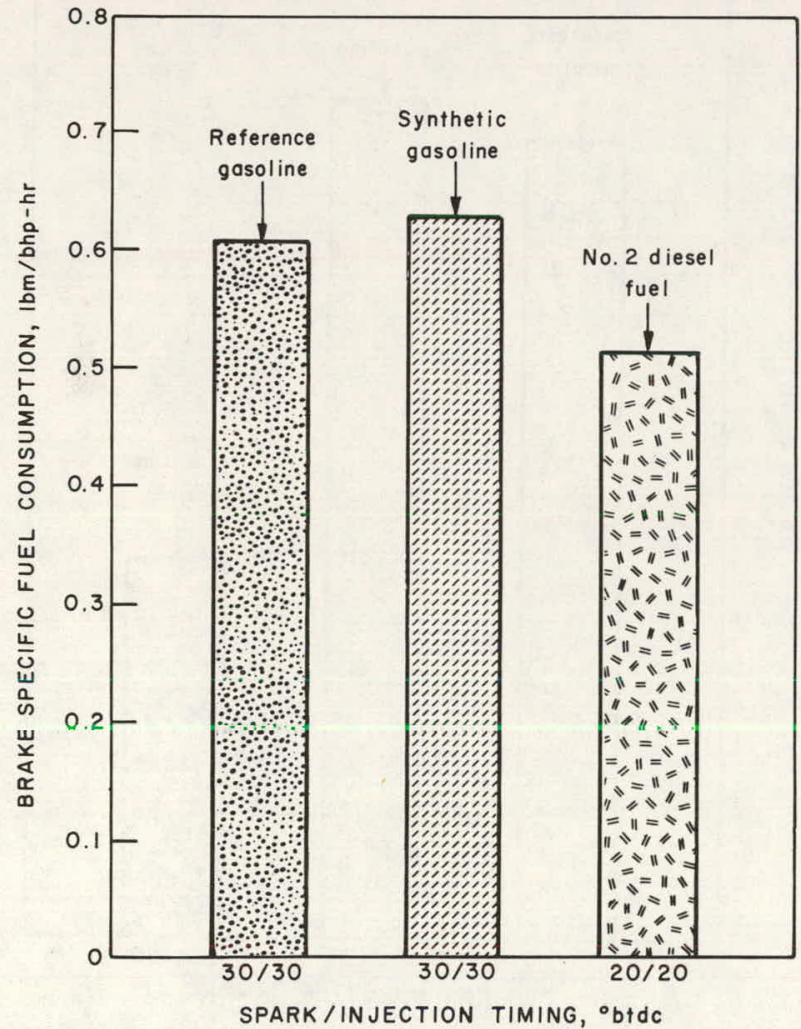

FIGURE 13. - Brake Specific Fuel Consumption of the White LIS-183 Engine Using Three Different Test Fuels at 2,000 rpm, 32 ft-1b Torque

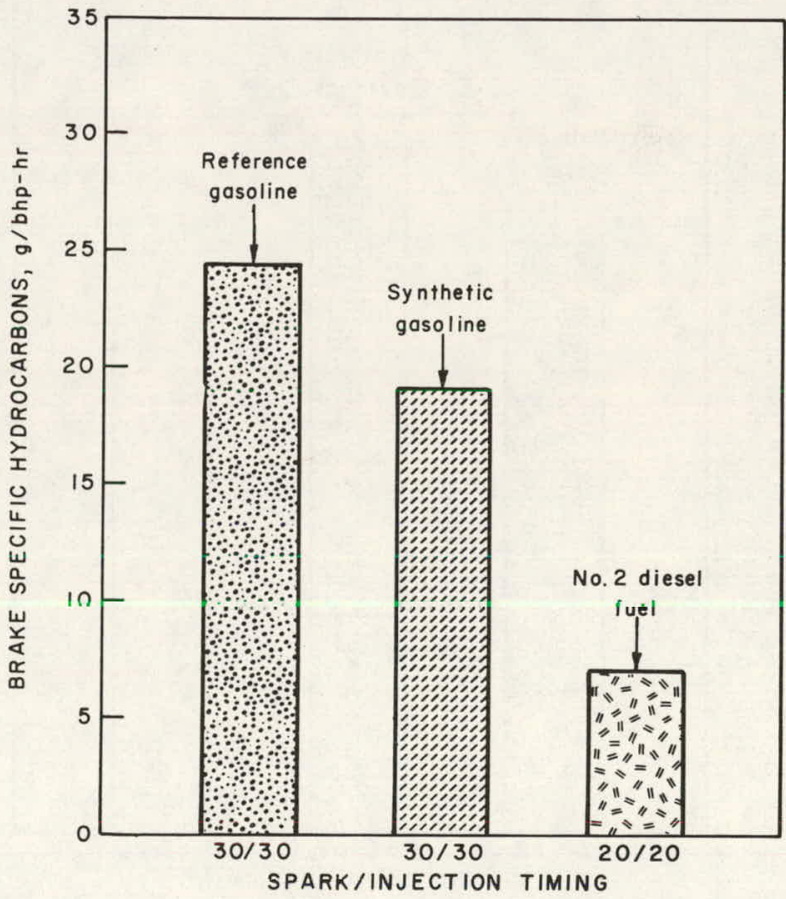

FIGURE 14. - Brake Specific Hydrocarbons of the White LIS-183 Engine Using Three Different Test Fuels at 2,000 rpm, $32 \mathrm{ft}-1 \mathrm{~b}$ Torque 
of the fuels. The diesel fuel had slightly lower CO emissions than the reference gasoline. The synthetic gasoline had slightly higher CO than the reference gasoline. The difference could be caused by fuel spray pattern changes due to different physical properties between the fuels. These changes could result in pockets of mixture at varying A/F ratio dependent on fuel type.

The $\mathrm{BSNO}_{\mathrm{X}}$ emissions (figure 16) show the diesel fuel to have approximately half the $\mathrm{NO}_{x}$ output of the reference gasoline and the synthetic gasoline. It was assumed that a large part of the increase in $\mathrm{NO}_{\mathrm{x}}$ emissions could be due to the difference in spark/injection timing (3). To see whether this was so, the synthetic gasoline and the reference gasoTine were burned in the engine at the same speed/load point, but with the same spark/injection timing $\left(20^{\circ}\right.$ BTDC) that was used with the No. 2 diesel fuel. The results (figure 17) show at equal spark/injection timing, there was no significant difference in $\mathrm{NO}_{\mathrm{x}}$ emissions between the three test fuels.

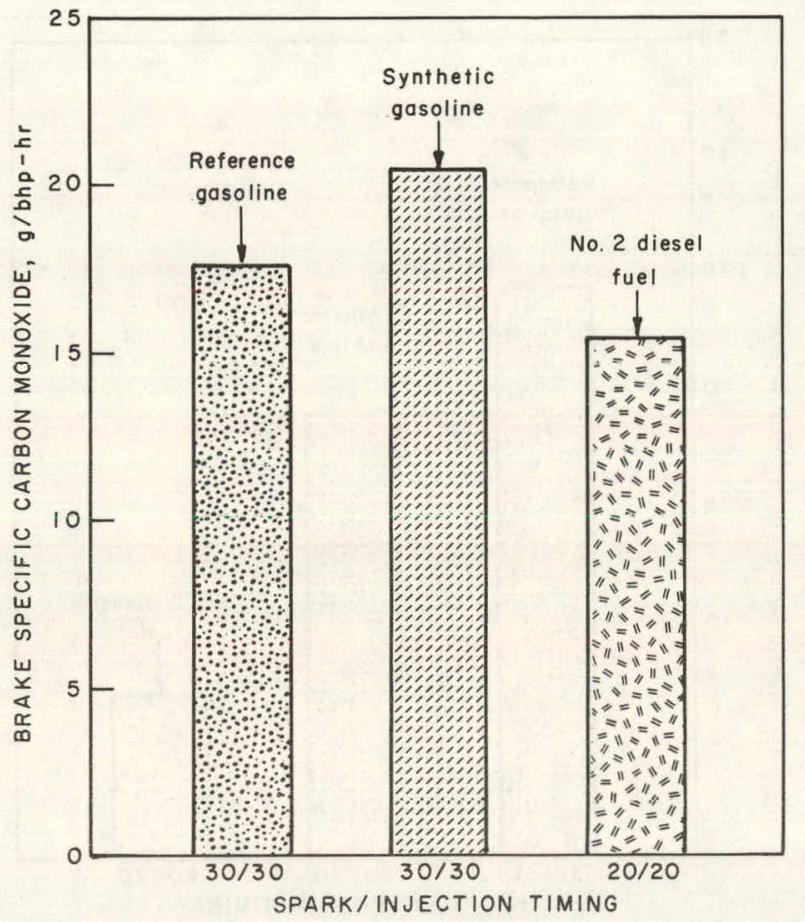

FIGURE 15. - Brake Specific Carbon Monoxide Emissions of the White LIS-183 Engine Using Three Different

Test Fuels at 2,000 rpm, $32 \mathrm{ft}-1 \mathrm{~b}$ Torque

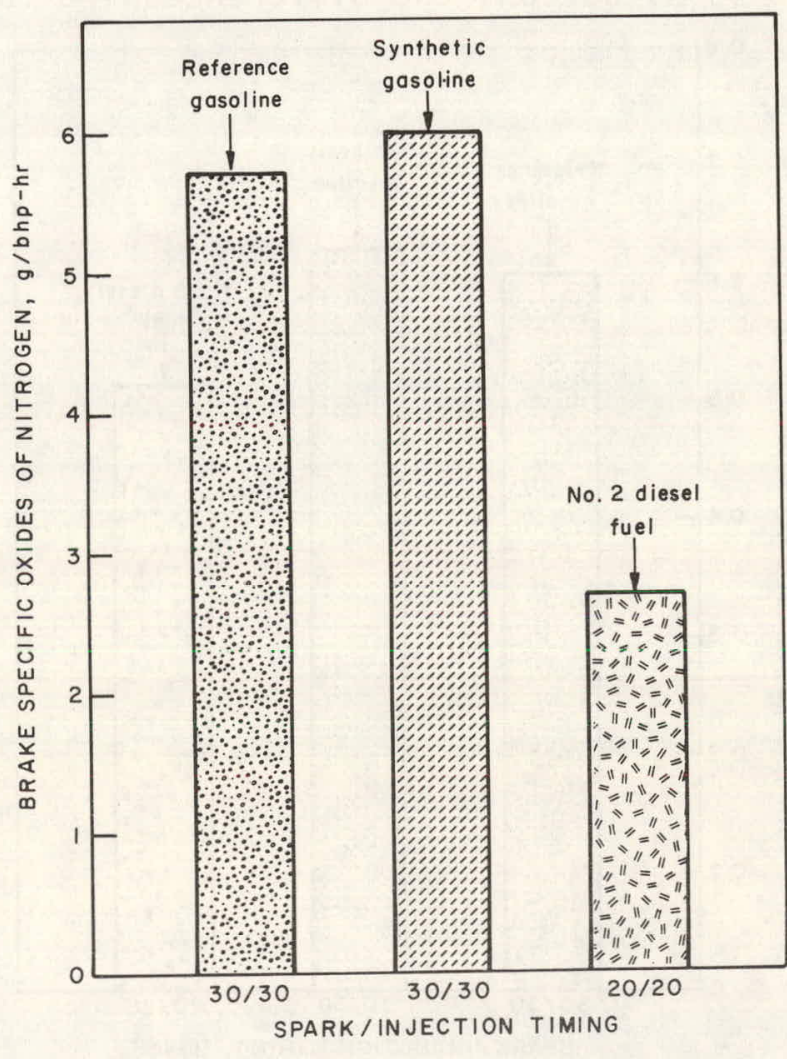

FIGURE 16. - Brake Specific 0xides of Nitrogen Emissions of the White LIS-183 Engine Using Three Different Test Fuels at 2,000 rpm, $32 \mathrm{ft}-1 \mathrm{~b}$ Torque 


\section{VEHICLE FUEL STUDY}

Synthetic fuels could influence current technology vehicles in terms of fuel economy and exhaust emissions. A vehicle study was conducted to compare the reference gasoline to the synfuel blend. Because of the low octane rating of the synthetic gasoline it was not possible to make a direct comparison (i.e., equal spark timing and compression ratio) between $i t$ and the reference gasoline. The comparison was made only between the reference gasoline and the synfuel blend. The objective was to show how the synthetic fuel with specifications inadequate for use directly in current production vehicles could be used through the addition of specific hydrocarbon types.

The vehicle chosen for this study was a 1977 Astre 2-door sedan. Its specifications (table 6) are representative of current vehicles of this size and weight. The tests chosen for evaluation of the fuels were the EPA urban and highway driving cycles plus fuel economy and exhaust

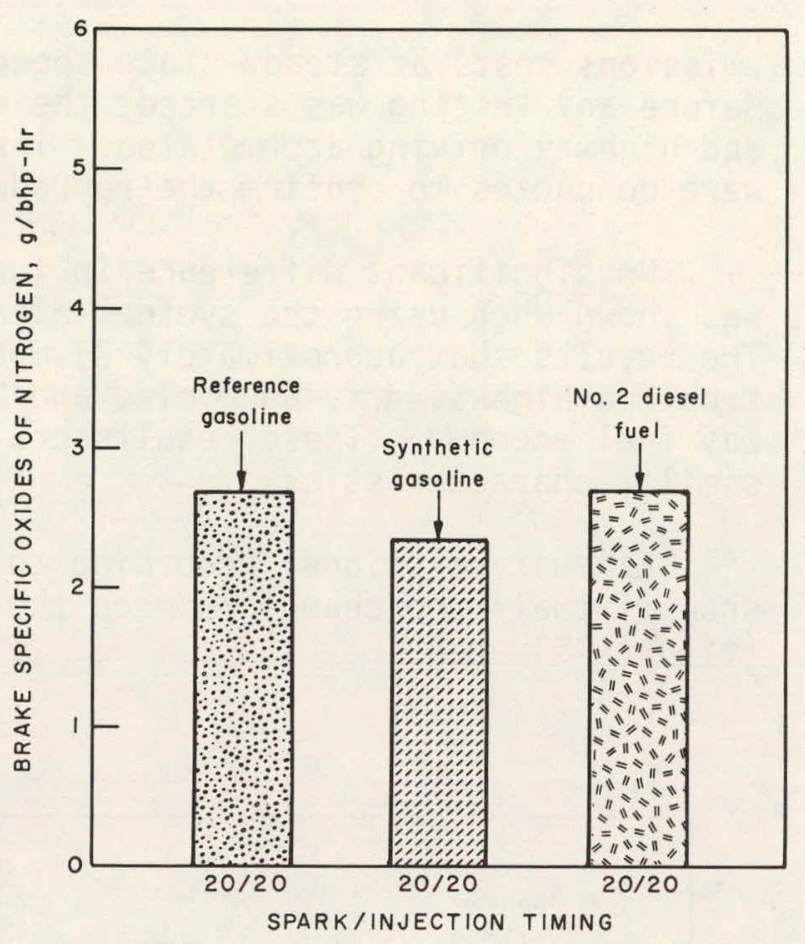

FIGURE 17. - Brake Specific 0xides of Nitrogen Emissions of the White LIS-183 Engine at Equal Spark/Injection Timing for Three Test Fuels at 2,000 rpm, $32 \mathrm{ft}-1 \mathrm{~b}$ Torque

TABLE 6. - Astre vehicle specifications

Engine........................

Displacement, cu. in............ 15

Horsepower...................

Carburetion................... 2-V

Compression ratio.............. 8.3 to 1

Emissions controls................ oxidation catalyst, exhaust-gaster and specified engine adjustments

EPA inertia weight class, $1 \mathrm{~b} \ldots \ldots .3,000$

Rear axle ratio................ 2.93

$\mathrm{N} / \mathrm{V}$ ratio o $50 \mathrm{mph} . \ldots \ldots \ldots \ldots \ldots . \ldots . \ldots 42.8$ 
emissions tests at steady-state speeds of $10,20,30,40,50$, and $60 \mathrm{mph}$. Before any testing was started, the vehicle had 2,000 miles of varied city and highway driving accumulated. Three dynamometer tests using each fuel were conducted to confirm the reproducibility of the results.

No significant difference in fuel economy of the vehicle (figure 18) was shown when using the synfuel blend compared to the reference gasoline. The results show approximately $21 \mathrm{mpg}$ from the urban driving cycle, $33 \mathrm{mpg}$ from the highway driving cycle, and $25 \mathrm{mpg}$ for the combined EPA urban/highway fuel economy. These results could be expected from two fuels with such similar characteristics.

Exhaust emissions, according to the 1975 Federal test procedure (FTP), show virtually no change between the reference fuel and the synfuel blend (figure 19).

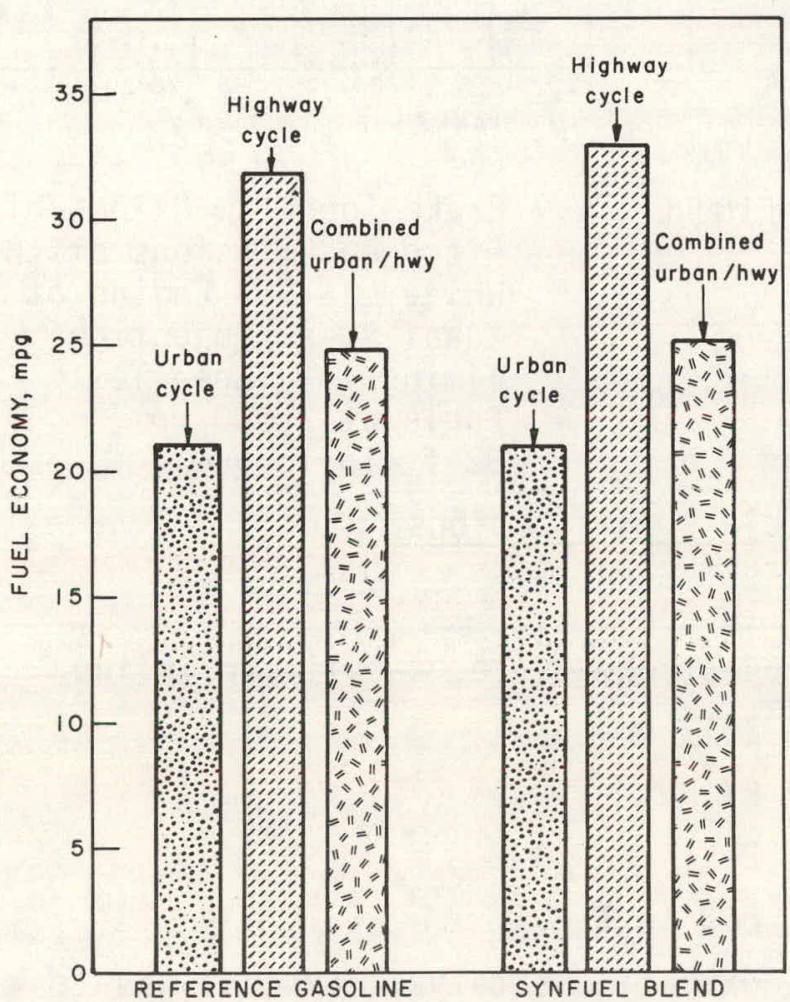

FIGURE 18. - Fuel Economy of the Astre Vehicle Over the EPA City and Highway Driving Cycles Using the Reference Gasoline and the Synfuel Blend

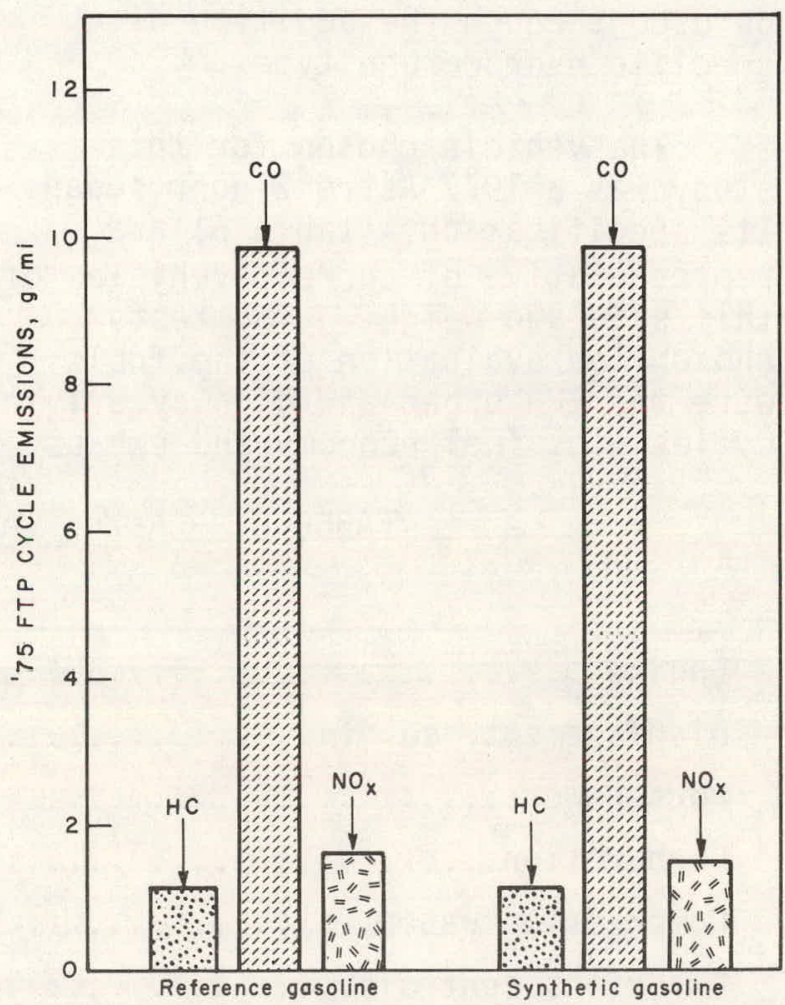

FIGURE 19. - Exhaust Emissions of the Astre Vehicle Over the 1975 FTP Driving Cycle Using the Reference Gasoline and the Synfuel Blend 
Steady-state fuel economy (figure 20) was similar using the reference gasoline and the synfuel blend. No detectable difference in driveability of the fuel occurred at any of the speeds tested.

The $\mathrm{HC}$ emissions at steady-state speeds show little difference between the synfuel blend and the reference gasoline (figure 21). The absolute value of HC's is very small at these speeds and road-load power. Because the values were so small, and steady operation is difficult to maintain, a fair degree of uncertainty existed at the speeds below $40 \mathrm{mph}$. From 40 to $60 \mathrm{mph}$, the $\mathrm{HC}$ emissions of the synfuel blend are just slightly lower than the reference gasoline and at these levels can be considered for all purposes the same.

Steady-state $\mathrm{CO}$ emissions show no significant difference between the reference gasoline and the synfuel blend (figure 22). If it is assumed that the fuel metering system was unaffected by any slight change in physical properties of the synfuel blend as compared to the reference gasoline, the air/fuel ratio was the same for each fuel. Assuming this, the synthetic gasoline has virtually no effect on $\mathrm{CO}$ emissions [CO emissions being mainly a function of air/fuel ratio (9) ]. The large spike of $\mathrm{CO}$ emissions at 20 $\mathrm{mph}$ is probably due to a transition in metering of the carburetor.

0xides of nitrogen emissions at the steady-state speeds tested showed no significant difference between the two fuels (figure 23). The $\mathrm{N}_{\mathrm{x}}$

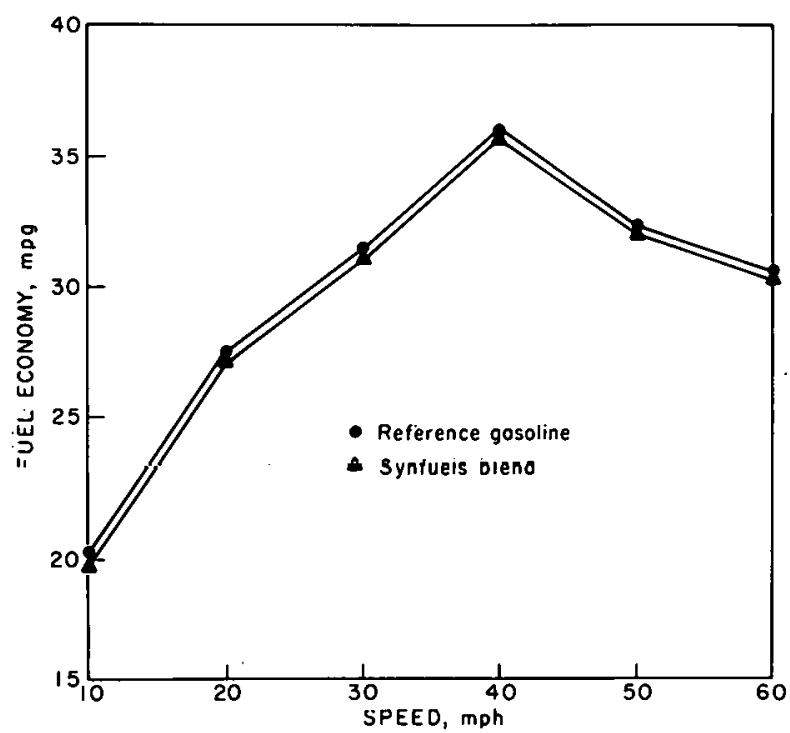

FIGURE 20. - Fuel Economy at SteadyState for the Astre Vehicle Using the Reference Gasoline and the Synfuel Blend

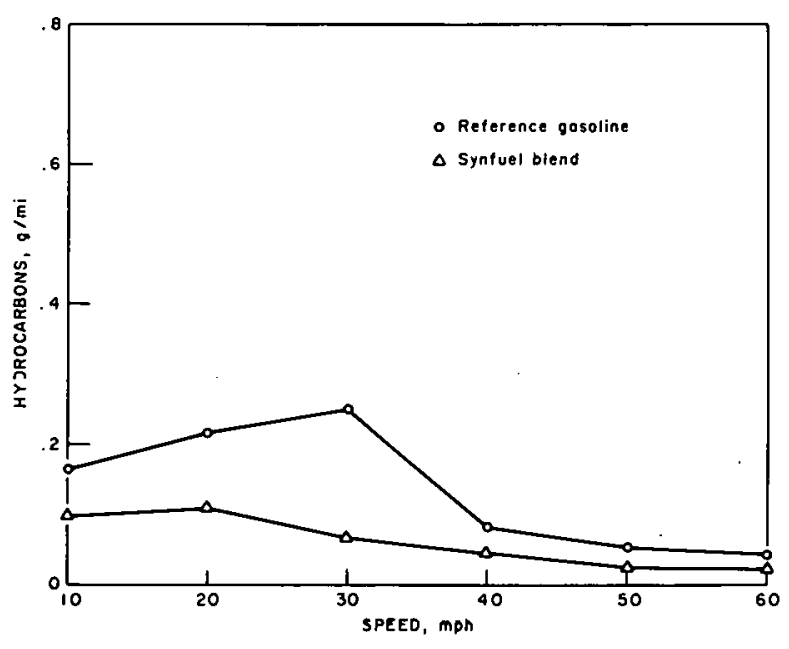

FIGURE 21. - Hydrocarbon Emissions at Steady-State Speeds for the Astre Venicle Using the Reference Gasol ine and the Synfuel Blend 


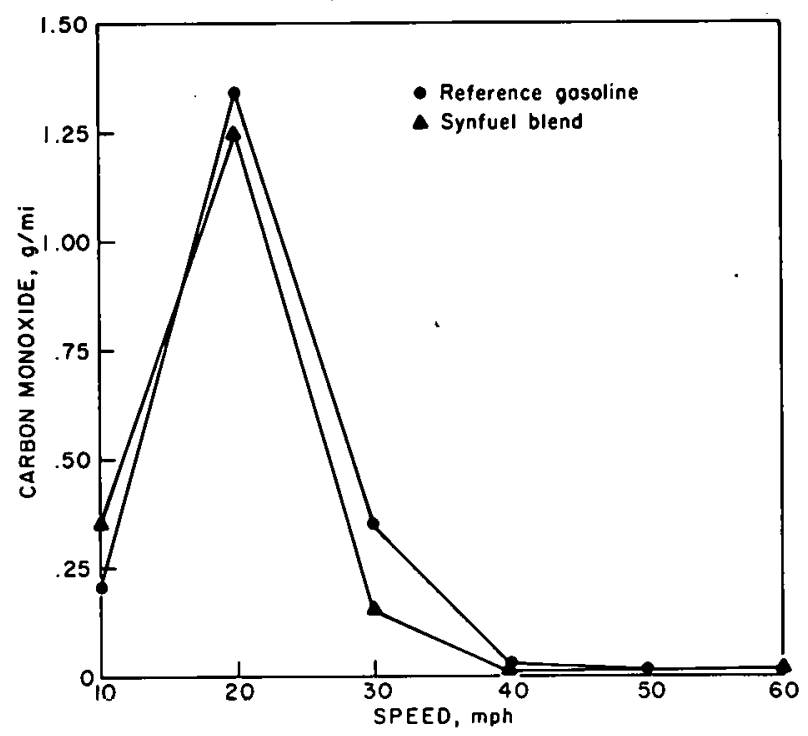

FIGURE 22. - Carbon Monoxide Emissions at Steady-State Speeds for the Astre Vehicle Using the Reference Gasoline and the Synfuel Blend

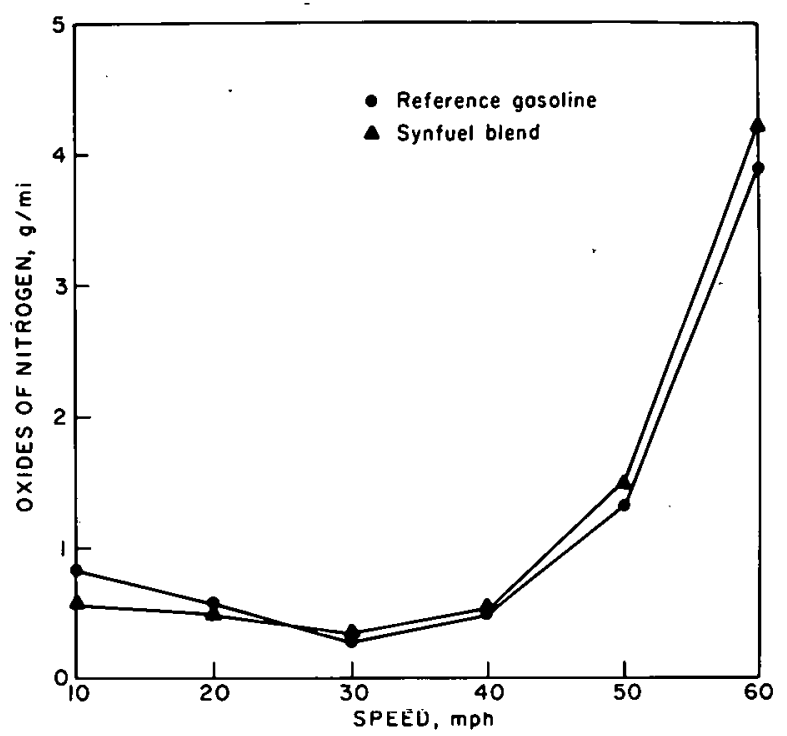

FIGURE 23. - 0xides of Nitrogen Emissions at SteadyState Speeds of the Astre Vehicle Using the Reference Gasoline and the Synfuel Blend

emissions are highly dependent on spark timing (3) which was held constant between the two fuels at each speed tested.

\section{DISCUSSION}

The synthetic gasoline as it was received is not directly compatible for use in current technology spark-ignition engines. Its motor octane rating of 70 requires that either the compression ratio be lowered or the spark timing be retarded from what would be optimum at present compression ratios. The single-cylinder test engine study has shown that if the compression ratio is lowered enough so that satisfactory operation is achieved (at MBT spark timing) an increase in fuel consumption of approximately 8 pct can be expected. (This result was obtained at only one speed/load point and is not representative of overall operation.) It is not likely that synthetic fuel such as this one would be put into widespread use in its present form.

Little change in exhaust emissions was noted between the reference gasoline, the synthetic gasoline, and the synfuel when used in the singlecylinder test engine. As for the fuel consumption results, these apply only to the speed/load point tested. The results over the entire operating range may be different and depend on the engine used. 
The results of this experimental study have shown that the synthetic gasoline and diesel fuel, derived from COED syncrude, are capable of being used in current technology engines. Due to the limited quantity of synthetic diesel fuel, test results were obtained only from the Stirling engine where no differences in fuel consumption or exhaust emissions were noted compared to the reference No. 2 diesel fuel at the speed/load point tested.

Using the synthetic gasoline in a fuel blend to power a current technology vehicle showed no blending problems, no significant change in fuel economy at steady-state speeds or over the EPA driving cycles, and no significant change in exhaust emissions. No driveability problems were encountered with the synthetic gasoline blend.

The White LIS-183 engine using a stratified-charge combustion system was able to burn the synthetic gasoline with no modifications or adjustments relative to the reference gasoline tested. No significant change in fuel consumption or exhaust emissions was noted between the two gasolines at the speed/load point tested. The multifuel capability of this engine allowed it to burn the synthetic gasoline with no modifications or adjustments. It could be assumed that this engine would also burn the synthetic diesel fuel since it ran satisfactorily on the reference No. 2 diesel fuel.

The Stirling engine with its continuous combustion system allowed operation with both the synthetic gasoline and the synthetic diesel fuel. In both cases, fuel consumption and exhaust emissions relative to the reference fuels showed no significant difference.

\section{SUMMARY}

The main results of this report are as follows:

Use of the synthetic gasoline in a single-cylinder, 4-stroke, sparkignition engine caused an increase in fuel consumption of about 8 pct at the speed/load point tested. A slight reduction in $\mathrm{HC}$ emissions was noted.

The synthetic gasoline fuel blend used in a vehicle showed no change in fuel consumption at steady-state speeds or over the EPA driving cycles. A small decrease in $\mathrm{HC}$ emissions was noted at steady-state speeds between 30 and $50 \mathrm{mph}$. No change in emissions was shown at the other steady-state speeds or over the EPA driving cycles.

The White LIS-183 engine with a stratified-charge combustion system was capable of burning the synthetic gasoline with no modifications or adjustments. No significant changes were shown between the synthetic gasoline and the reference gasoline with respect to fuel consumption, $\mathrm{CO}$, and $\mathrm{NO}_{\mathrm{X}}$ emissions. A slight decrease in $\mathrm{HC}$ emissions occurred with the synthetic gasoline.

The Stirling engine could burn either the synthetic gasoline or synthetic diesel fuel with no modifications. No significant differences in fuel consumption or exhaust emissions were noted between the synthetic fuels and their reference counterparts at the speed/load point tested. 


\section{REFERENCES}

1. Daniel, W. A. Why Engine Variables Affect Exhaust Hydrocarbon Emission. Pres. at the Automotive Engineering Congress, Detroit, MI, Jan. 12-16, 1970, SAE Paper No. 700108,28 pp.

2. Evers, L. W., R. D. Fleming, and R. W. Hurn. Efficiency of a Stratified Charge Engine Optimized for Various Fuels. Pres. at the SAE Congress and Exposition, Detroit, Michigan, Feb. 27-March 3, 1978, SAE Paper No. $780236,11 \mathrm{pp}$.

3. Huls, T. A., and H. A. Nickol. Influence of Engine Variables on Exhaust Oxides of Nitrogen Concentrations from a Multi-Cylinder Engine. Pres. at the SAE Mid-Year Meeting, Chicago, IL, May 15-19, 1967, SAE Paper No. 670482, 12 pp.

4. Jackson, M. W., W. M. Wiese, and J. T. Wentworth. The Influence on AirFuel Ratio, Spark Timing, and Combustion Chamber Deposits on Exhaust Hydrocarbon Emissions. Pres. at the SAE National Automobile Week, Detroit, MI, March 12-16, 1962, SAE Paper No. 486A, 26 pp.

5. Jacobs, W. L., and D. P. Thornton, Jr. Series Flow Hydrocracking Gives a Choice of Products. Chemical Engineering, Nov. 16, 1970.

6. Johnson, P.W. Nitrogen Oxide Emissions from the Gasoline Engine.

Shell Research Limited, Thornton Research Centre, Paper No. MOR 438 F, June 1969, $49 \mathrm{pp}$.

7. Jones, J. F. Project COED (Char-0i1-Energy Development). Symposium papers, Clean Fuels from Coal. Institute of Gas Technology, IIT Center, Chicago, IL, Sept. 10-14, 1973, pp. 383-402.

8. Obert, Edward F. Internal Combustion Engines and Air Pollution, ed. by E. F. Obert. Intext Educational Publishers, New York, 1973, pp. 166-169.

9. Internal Combustion Engines and Air Pollution, ed. by E. F. 0bert. Intext Educational Publishers, New York, 1973, pp. 356-358.

10. Shelton, E.M. Diesel Fuel 0i1, 1976. ERDA/BERC/PPS-76/5, November 1976, $35 \mathrm{pp}$.

11. Sikonia, John G., William L. Jacobs, and Stanley A. Gembicki. UOP Distillate Hydrocracking: New Developments Offer Increased Capability. Pres. at the 43rd Mid-Year Meeting of the American Petroleum Institute, Toronto, Canada, May 8-11, 1978.

12. Synthetic Fuels Processing, ed. by Arnold H. Pelofsky. Marcel Dekker, Inc., New York and Bansel, 1977, 473 pp. 